\title{
グループに着目した 朝市来訪者の行動特性と環境影響
}

\author{
氏原岳人 1 ・谷口 守 $2 \cdot$ 松中亮治 3 \\ 1学生会員 岡山大学大学院環境学研究科社会基盤環境学専攻（下 700-8530 岡山市津島中3-1-1） \\ E-mail:gev17105@cc.okayama-u.ac.jp \\ 2正会員 岡山大学大学院環境学研究科社会基盤環境学専攻（广700-8530 岡山市津島中3-1-1） \\ E-mail:mamoru34@cc.okayama-u.ac.jp \\ 3 正会員 岡山大学大学院環境学研究科社会基盤環境学専攻（广700-8530 岡山市津島中3-1-1） \\ E-mail:matsu@cc.okayama-u.ac.jp
}

\begin{abstract}
朝市などの非定常型のマーケットを中心市街地再生のきっかけにしようとする試みが現在各所で行われ ている.このような朝市の買い物行動は, 日常のそれと比較してグループ来訪に卓越した点が見られると 類推される. そこで本研究では倉敷市で開催される朝市の来訪者にアンケート調查を実施し, グループ行 動の基本的な特性，及び関連する要因を定量化した。分析の結果，単独来訪者と比較して，グループ来訪 者は朝市を非日常的なレジャーと明確に位置づけており，その一方でグループ来訪者のリピート性や支出 額は単独来訪者より相対的に低いことも明らかになった。ささに，いわゆる観光地を訪れるグループ行動 と比較して, 朝市へのグループ来訪者の交通環境負荷は低く抑えられていることをあわせて明らかにした.
\end{abstract}

Key Words : group behavior, urban renewal, life style, mode choice, environment

\section{1. はじめに}

\section{(1) 研究背景と目的}

わが国では，これまでの急激なモータリゼーションの 進展や郊外化，また，それに伴う人々のライフスタイル の変化により，これまでの賑わいの中心的な場所であっ た中心市街地は衰退の一途を辿っている.このような状 況に対し，全国各地で中心市街地の再生を目的とした 様々な方策が自治体や民間団体により実施されている. 本研究において対象とする倉敷市もそのような自治体の 典型例といえる. 郊外大型ショッピングセンターの進出 やJR倉敷駅に隣接する老舖デパートの撤退など，中心市 街地衰退を助長する動きが止まらない。一方で，中心市 街地の活性化を主目的とした地産地消型の「くらしき朝 市」がJR倉敷駅前商店街で2005年3月より月一度開催さ れており，後述するように来訪者も多く，期待を集めて いる.

そして，商店街のような（その土地に立地した）定常 型のマーケットと比較すると, 非定常型のマーケットで あるこのような朝市の買い物行動は, レジャーや観光の 要素が強いと考えられるため, 家族や友人・知人という ようなグループを単位とする来訪者（以下，グループ来 訪と呼ぶ）の行動には，日常的な買い物行動と比較して,
卓越した点が見られると考えられる.

また，グループ来訪か，もしくは単独者による来訪 （以下，単独来訪と呼ぶ）かによって行動実態や意識が 異なることも類推される. ただ，そのようなごく基本的 な事柄も, 現在までに十分な調査に基づいて報告された 例はなく，実態はよくわかっていない．

本研究では, グループ来訪と単独来訪の行動・意識の 比較を現地でのアンケート調査をもとに実施し，その実 態を明らかにする. 基本的な行動特性やその諸要因（意 識)を定量的に示す事で，朝市など中心市街地における 非定常型マーケットでのグループ来訪行動の実態と特徵 を初めて明らかにすることを目的とする。

\section{（2）既往研究と本研究との位置づけ}

グループに着目した交通行動について, 本報告とは異 なる対象や観点からその理論化や実態にアプローチしよ うとした例は以前から見られる. 例えば1995年12月に行 われた土木計画学のスペシャルセッション「交通行動理 論の新展開」において, 上田・森杉1) は複数個人から形 成される家族の内部相互作用について議論している. 近 年では, 張ら゙りにより, 中山間地域の高齢者世帯を対象 として, 送迎などの交通行動と活動に関する意思決定に 存在する世帯内相互作用やその異質性を考慮した世帯時 
間配分モデルの構築を行い，その有効性を明らかにして いる.

一方で，観光に関する交通行動については現在までに 幅広い研究引がなされており，その環境影響にまで言及 した研究)もある．その中でグループ行動の実態に迫ろ うとする研究は, 交通手段選択に着目した武藤・内山 ${ }^{5}$ の研究など非常に限られている. そこではモデル的手法 を用いることでグループ属性（家族，友人・知人）やグ ループ人数が手段選択に及ぶ影響が検討されている．さ らに，朝市を含む休日や観光地における交通行動に関し て言えば，例えば，先述のようなモデル的手法を用いて 何を明らかにすべきなのか，また，明らかにされた事象 を，どのように計画に取組んでいくのかなどが重要な事 項となってくる. このような折り, 昨今では, 土木学会 土木計画学委員会のにおいて，「休日・観光交通研究小 委員会」が新たに設置されるに至っており, それら事項 への取り組みの重要性が高まってきている.

また，朝市などの非定常型マーケットの来訪者を対象 とした研究は限られているが，日暮・安村》によって朝 市を利用する消費者の特徽を消費者行動から分析したも のがある. しかし，これらは朝市を利用する消費者の市 場選好パターンを明示したものであり，朝市来訪の際の 行動を，実データに基づいて明らかにしたものではない， また，湯沢・星 ${ }^{8}$ は，消費者に対する意識調査結果を用 いて，因子分析等を行うことで，朝市（定期市）を含む， 異なる商業施設の位置づけを明確にしている.この研究 では，マーケティングの視点から，各商業施設の中でも， 朝市のその特異性を明確に示している点で，とても意義 深い.しかし, 日暮らの研究と同様に, 朝市来訪の際の 行動には触れられていない. 寸なわち，一般的な定常型 マーケットと比較して，非定常型マーケットである朝市 の特異性が，ある観点から明確にされいるにも関わらず， 朝市はもとより, 非定常型マーケットの来訪時における 行動や意識を定量的に明らかにしたものは見られない.

このような状況にあるため, 無論, グループ来訪に対す る視点も含まれていない.

以上のような関連分野の既存研究に対し, 本報告は次 のような特長と位置づけを有する.

1）グループ来訪者と単独来訪者の行動特性やその要 因に関する基本的な特徵を，実データをもとに比 較検討する.

2）対象とする行動は，いわゆる交通需要予測の際に 問題となる「交通手段選択」にとどまらず，都心 再生などを検討する際に重要な事項となる「評価 意識（総合満足度）」，「リピート性（訪問回 数）」,「にぎわいへの貢献（滞在時間）」, 「地元経済への貢献（支出額）」を検討対象とす
る（（）内は具体的な指標名をあらわす．）

3）付帯的な検討として, 朝市のような都心再生型の グループ観光が，従来のごく一般的なグループ観 光と比較してどのような交通特性をもち, 環境負 荷の面でどのような意義があるのかを検討する.

4）報告の全体を通し，十分なサンプル数に基づいた 信頼性の高い分析を行う。

\section{2. 使用データと分析内容}

\section{（1）くらしき朝市およびアンケート調査の概要}

「くらしき朝市」（以下，朝市と呼ぶ）は2005年3月 から毎月第3日曜日の午前8時から11時まで，JR倉敷駅前 の商店街にて，「地産地消」をコンセプトとして開催さ れており, 地元の農産物などを販売する約 80 店舗が出店 している. なお，この朝市会場は美観地区とチボリ公園 のちょうど中間点に存在し，そのいずれにも400m歩けば 容易に徒歩でアクセスできる.

アンケート調査は朝市会場における各コードンライン 通過者（帰宅）をランダムに抽出し，その場で，岡山大 学社会システム計画学研究室による聞き取り調査を実施 したものである（表-1）。同時にコードンラインの通過 者カウント調査も実施しており, 調査時間帯の来場者 8,906名のうち，3.6\%を抽出したことになっている. なお， この抽出率は，実際の交通計画等に用いられる都市パー ソントリップ調査のそれに匹敵するものである.

\section{（2）分析内容}

以下では, まず3章において, 朝市の来訪者構成を明 らかにするとともに, 日常の買い物行動と比較して, ど のような差異があるのかを把握する，そして，4章では， グループ人数やグループ特性によって, グループ来訪者 の行動特性にどのような特徵があるかを把握する. グル 一プ特性としては，「家族グループ」，「友人・知人グ ループ」の 2 タイプを想定する.また分析の視点として， 先述したように，1）交通手段選択，2）評価意識(総合満 足度)，3）リピート性（訪問回数），4）にぎわいいの貢 献（滞在時間），5）地元経済への貢献（支出額）の5指 標について，集計分析をべースとした実態の検討を行う。 次に，5章において，4章で明らかにされたようなグル 一プ来訪者の都市再生に関わりの深い行動特性2)～5）の

表-1 アンケート調査の概要

\begin{tabular}{|c|c|}
\hline 調查日時 & 平成17年7月17日（日） \\
\hline 調查場所 & 「くらしき朝市」会場各出入りロ（全7箇所） \\
\hline 聴取サンプル数 & 318 \\
\hline \multirow{4}{*}{ 主要調査項目 } & 個人属性：年齢, 性別, \\
\hline & 意識：総合満足度, 訪問理由（表-2参照） \\
\hline & 交通：交通手段, 訪問経路, 滞在時間 \\
\hline & その他：訪問回数, 支出額, 後の予定 \\
\hline
\end{tabular}


それぞれが，どのような意識により規定されているのか を数量化モデルを用いて検討を行う。なお，ここで行動 を規定している意識（説明変数）と想定したのは，表-2 に示すとおり，A．商品の魅力，B．立地の良さ，C．朝 市の雾囲気，D．その他の大分類からなる計13項目の朝 市訪問理由に関する回答結果である.

さらに，6章においては，行動特性の中の，1)交通手 段選択を環境の視点から捉える. 具体的には, 単独来訪 者とグループ来訪者の環境負荷の違い，及び従来型観光 地に訪れるグループ来訪者と, 朝市グループ来訪者との 環境負荷の違いを概観し，考察を加える.

\section{3. 朝市の来訪者構成}

ここでは，朝市の来訪者構成を明らかにするとともに， 日常的に行われる平休日の買い物行動と比較して, どの ような差異があるのかもあわせて考察する。図-1は来訪 者のグループ人数および, クループ属性を示している. その結果, 単独来訪者と比較して, グループ来訪者が 60\%以上と高く，さらに，その中でも家族での来訪割合 が高いことが分かる. なお, 既存研究9を参考にして, 平日の買い物行動と比較すると, 朝市のグループ来訪者 割合は顕著に高い一方で，休日の買い物行動と比較する と相対的に低い結果となった．また，グループ属性に着

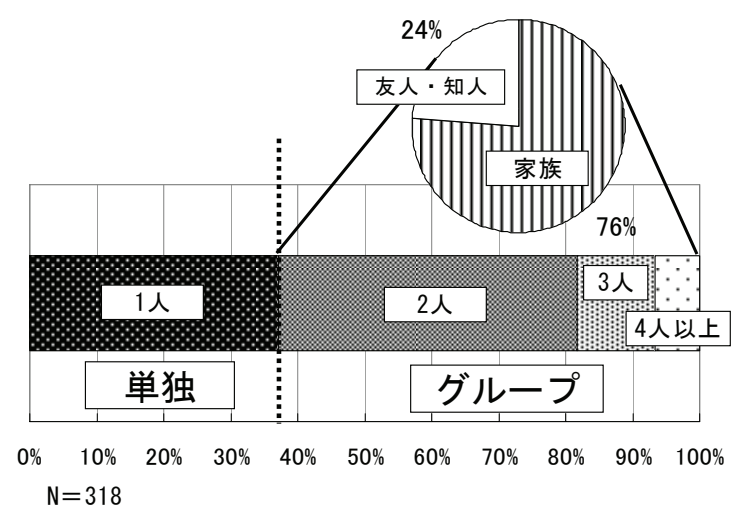

図-1 朝市の来訪者構成

表-2 朝市訪問理由に関する質問内容

\begin{tabular}{|c|c|c|}
\hline 分類 & 番号 & 訪問理由 \\
\hline \multirow{4}{*}{ A. 商品の魅力 } & & 品物が安い \\
\hline & A2 & I品物が新鮮だ \\
\hline & & |飲食を含めて他にない商品が買える \\
\hline & & |顔の見える商品が購入できる(生産者直売) \\
\hline \multirow{4}{*}{ B.立地の良さ } & & |商店街や駅周辺での買い物のついでに立寄れる \\
\hline & & |徒歩や自転車で, 車がなくても来れる \\
\hline & B3 & 近くに駐車場が多い \\
\hline & B4 & 駅に近く, バスや電車が利用できる \\
\hline \multirow{3}{*}{ c.朝市の雰囲気 } & & |お祭り気分が味わえる \\
\hline & & |朝市が好き(他の朝市も好き) \\
\hline & & 身近なレジャ一感覚で来れる \\
\hline \multirow{2}{*}{ D.その他 } & & 犮人·知人が出店している \\
\hline & & ;美観地区，またはチボリ公園と組合わせて楽しめる \\
\hline
\end{tabular}

目した場合, 朝市は友人・知人での来訪割合が，平休日 のそれと比較して, 相対的に高い点が特徽的であった.

\section{4. グループ来訪者の行動特性に関する基礎的分 析結果}

以下では，グループ来訪者の行動特性を，基本的な5 指標 1) 交通手段選択，2) 総合満足度，3) 訪問回数，4) 滞在時間，5) 支出金額）について比較する. なお，グル ープ来訪者については，さらに人数で細分化した場合と， グループ属性(家族，友人・知人)で細分化した場合の両 方について考察を加える. 各行動特性とグループ属性等 については, 独立性の検定を行っており, 有意差が認め られる場合には，さらに残差分析を行うことで, 項目間 における詳細な検討も行った. 独立性の検定結果を表-3 に示す.

また，支出金額については，家族グループにはグルー プあたりの支出金額を，友人・知人グループには，1人 あたりの支出金額を聞き取っており，それを基に算出し ている. その他の指標は, 回答者ベースのものである.

\section{（1）交通手段選択}

図-2に交通手段選択の構成比を示寸，なお，検定結果 より, 全ての検定対象において有意差が認められた.こ のため，それら全てにおいて残差分析を行っている，そ の結果, グループ来訪者は単独来訪者と比較して, 自家 用車利用が有意に高い ( $1 \%$ 水準)一方で，自転車利用およ び，公共交通利用は有意に低い(自転車利用：1\%水準， 公共交通利用: $5 \%$ 水準)。なお, 単独来訪者の自家用車 利用は3割にも達していない，さらに，家族グループは， 単独来訪者や友人・知人グループと比較して, 自家用車 利用が有意に高い( $1 \%$ 水準) のに対して，友人・知人グル 一プは，鉄道利用が有意に高い(5\%水準)点が特徵的であ る. すなわち, グループ来訪者は自家用車を利用する傾

表-3 各行動特性の検定結果

\begin{tabular}{|c|c|c|c|c|c|}
\hline 行動特性 & 検定対象注） & $x^{2}$ 值 & 自由度 & $\mathrm{P}$ 值 & 判 定 \\
\hline \multirow{3}{*}{$\begin{array}{l}\text { (1) 交通手段 } \\
\text { 選択 }\end{array}$} & 単独·グループ & 27.9 & 5 & 0.000 & *** \\
\hline & グループ人数 & 42.1 & 15 & 0.000 & ** \\
\hline & グループ属性 & 21.4 & 8 & 0.006 & ** \\
\hline \multirow{3}{*}{ (2)総合満足度 } & 単独·グループ & 6.0 & 3 & 0.114 & \\
\hline & グループ人数 & 17.2 & 9 & 0.046 & $*$ \\
\hline & グループ属性 & 6.2 & 6 & 0.396 & \\
\hline \multirow{3}{*}{ (3)訪問回数 } & 単独·グループ & 14.7 & 4 & 0.005 & ** \\
\hline & グループ人数 & 22.6 & 12 & 0.031 & * \\
\hline & グループ属性 & 21.4 & 8 & 0.006 & ** \\
\hline \multirow{3}{*}{ (4)滞在時間 } & 単独·グループ & 5.4 & 4 & 0.253 & \\
\hline & グループ人数 & 15.0 & 12 & 0.241 & \\
\hline & グループ属性 & 12.5 & 8 & 0.129 & \\
\hline \multirow{3}{*}{ (5)支出金額 } & 単独·グループ & 16.6 & 4 & 0.002 & ** \\
\hline & グループ人数 & 33.3 & 12 & 0.001 & $* *$ \\
\hline & グループ属性 & 35.7 & 8 & 0.000 & ** \\
\hline
\end{tabular}




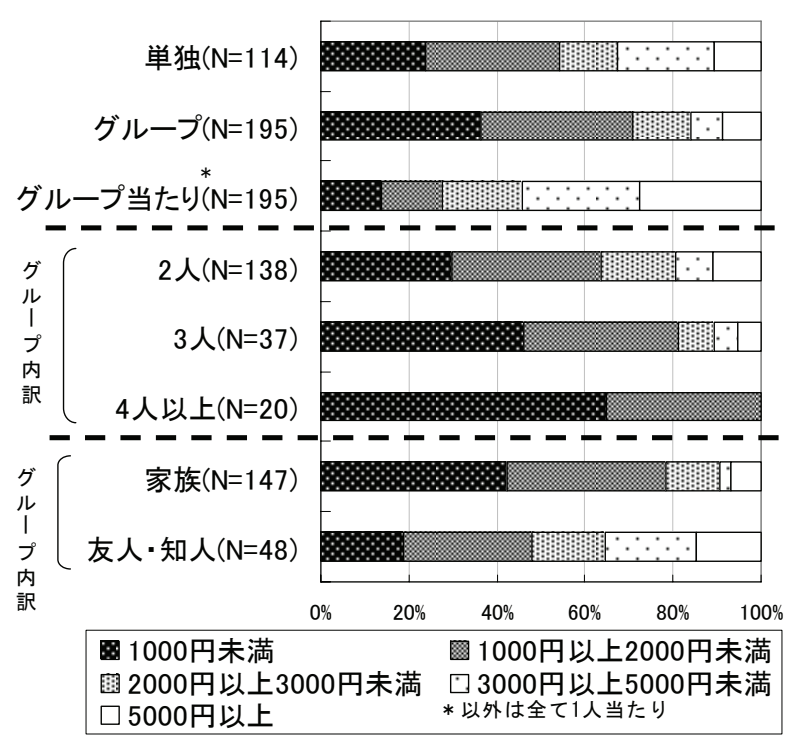

図-6 来訪者構成と支出金額の関係

を対象とした既存研究 ${ }^{10} に$ にると, これら傾向とは逆に, 友人・知人グループより, むしろ家族グループの方が滞 在時間が長いという結果が得られている.

\section{(5) 支出金額}

図-6に来訪者構成と支出金額の関係を示寸，なお，検 定結果より，全ての検定対象において，その有意差が認 められており, このため, それらにおいて, 残差分析を 行った. その結果, 顕著な傾向として, グループ来訪者 の「1,000円未満」が有意に高いのに対して，単独来訪 者のそれは有意に低い(ともに5\%水準)。その一方で，グ ループ来訪者の「3,000円以上5,000円未満」は有意に低 いのに対して，単独来訪者のそれは有意に高い(ともに 1\%水準)。また，「1,000円未満」の来訪者はグループ人 数が増加するほど, 高くなり，3人および，4人以上のグ ループでは，他と比較して，有意に高くなる(3人： $5 \%$ 水 準，4人以上: $1 \%$ 水準)。さらに，グループ属性に着目す ると，家族グループの「1,000円未満」が有意に高い( $1 \%$ 水準)一方で，友人・知人グループのそれは有意に低い (5\%水準)。また，「3,000円以上5,000円未満」においては, その逆傾向が有意に見られる(ともに $1 \%$ 水準)。すなわち, グループ来訪者は単独来訪者と比較して, 支出金额が相 対的に低く，その傾向は，家族グループにおいて顕著で あると言える。

以上のことを総合すると, 次のようなグループ行動の 特性が浮き彫りになってきたといえる. 寸なわち, グル 一プ来訪者は, 自家用車を手段として選択寸る傾向が強 く, その傾向は家族グループで更に顕著となる。 また, リピーターの割合は相対的に少ない，さらに，滞在時間 が長いにも関わらず，支出金額が低い，その一方で，単 独来訪者は，徒歩や自転車などで訪れる傾向が高く，訪
問回数も多い(リピート性も高い)。また, 滞在時間が短 いにも関わらず，支出金額が高い，そして，朝市に対す る総合満足度については, 両者の間に大きな差はなく, ほとんどの来訪者が満足している.

\section{5. グループ来訪者の意識に関するモデル分析}

本章ではグループ来訪者による, 都市再生に関わりの 深い行動特性2)～5) のそれぞれが，どのような意識で規 定されているのかを数量化IIモデルを用いた検討から考 察する．なお，本報告で掲載した総合満足度および，訪 問回数において，単独来訪者とグループ来訪者との母平 均に差があるかどうか判断するために， t検定を行って いる. その結果, それぞれに有意差(総合満足度 : $5 \%$ 水 準，訪問回数：1\%水準)が認められた.

\section{（1）総合満足度に影響する要因}

図-7，8に，単独来訪者，グループ来訪者ごとに「総 合満足度」に表-2で示した13の各訪問理由がどの程度, 影響しているのかを, 数量化林類モデルを用いて検討を 行った結果を示寸．なお，以下のいずれのモデルでも13 すべての変数を含めてモデル分析を行っているが，紙数 の関係上それぞれのモデルにおいて，偏相関係数の高い 順に4変数のみを掲載している.

図-7より，単独来訪者は「品物が新鮮だ」，「商店街 や駅周辺の買い物のついでに立寄れる」「品物が安い」 など日常の買い物の効果的な代替を朝市に期待するかど うかで，その総合満足度に大きな影響が及ぶことが明ら かとなった。その一方, 図-8より, グループ来訪者は 「品物が安い」という買い物の要素も一部で考慮する反 面，単独来訪者が重視しなかった「お祭り気分が味わえ る」「飲食を含めて他にない商品が買える」など, 朝市 を非日常的なものと捉えるかどうかで, 総合満足度が大 きく異なることが示された．図-3の総合満足度に対する 単純集計のレベルでは，単独とグループの意識の差異は それほど明確なものではなかったが, 満足の要因という 面では，このようにその内容に大きな差があることが明 らかになった. なお, 単独来訪者, グループ来訪者とも 「友人・知人が出店している」が総合満足度に対して同 じように負に影響しているのは興味深い点である。これ は，人間関係上「行かないと悪い」という義務感に基づ いて来訪した人は，朝市に対する総合満足度が相対的に 低くなっていることを示している．店側と客側が顔見知 りである地方部での類似行事開催においては注意が必要 な点といえる. 


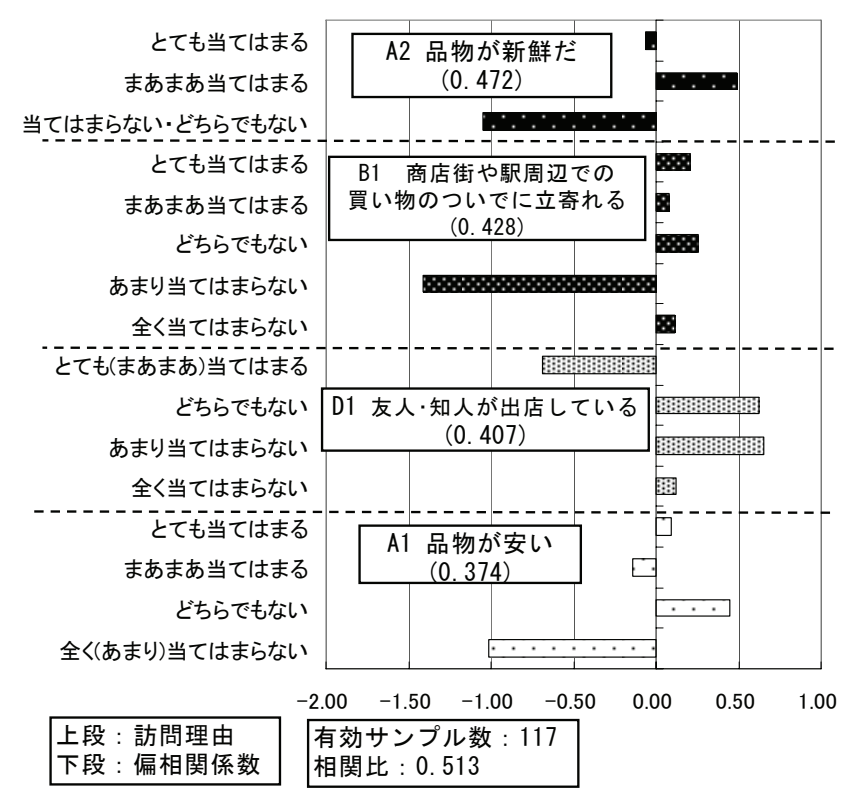

図-7 単独来訪者における総合満足度要因分析 (数量化 II 類モデル : 偏相関係数の高い順に4つを掲載)

\section{（2）訪問回数に影響する要因}

外的基準となる訪問回数は比率尺度であるため, ここ では数量化類モデルを用いて分析を実施した．単独来 訪者の結果を図-9，グループ来訪者の結果を図-10に示 す. なお，サンプル数の関係から，利用交通手段が異な る来訪者も同一のモデル中に含まれている．このため, 変数によっては，カテゴリ一值の傾向に規則性がないも のも含まれており，その点は解釈上の注意が必要である

（図-9「B4. 駅に近く，バスや電車が利用できる」：公 共交通利用に関係なく訪問回数の多い来訪者が「どちら でもない」に回答し，公共交通を利用する，もしくは利 用しない訪問回数の少ない来訪者が，「とても・まあま あ当てはまる」もしくは「全く・あまり当てはまらな い」に回答しているケース。 また，図-10の「B3. 近くに 駐車場が多い」: 訪問回数の多い自家用車利用者の多く が「とても当てはまる」に回答し，一方で訪問回数の多 い徒歩来訪者の多くが「全く当てはまらない」に回答し ているケース。このようなケースは，両極端の選択肢の カテゴリー值が共にマイナスもしくはプラスになってい るが，上記のような理由より，規則性の無い結果が生じ る事は容易に類推できる。）

図-9,10より，単独，グループ来訪者とも，「徒歩や 自転車で，車がなくても来れる」の偏相関係数值が高く， 朝市会場が徒歩や自転車でアクセスできる生活圈域内で あることが訪問回数に影響していることがわかる．また， この傾向はグループ来訪者より単独来訪者の方が強いと いえる. 一方，グループ来訪者は「身近なレジャ一感覚 で来れる」という意識が訪問回数に顕著に影響しており 単独来訪者のリピート理由とは大きく異なる点といえる.

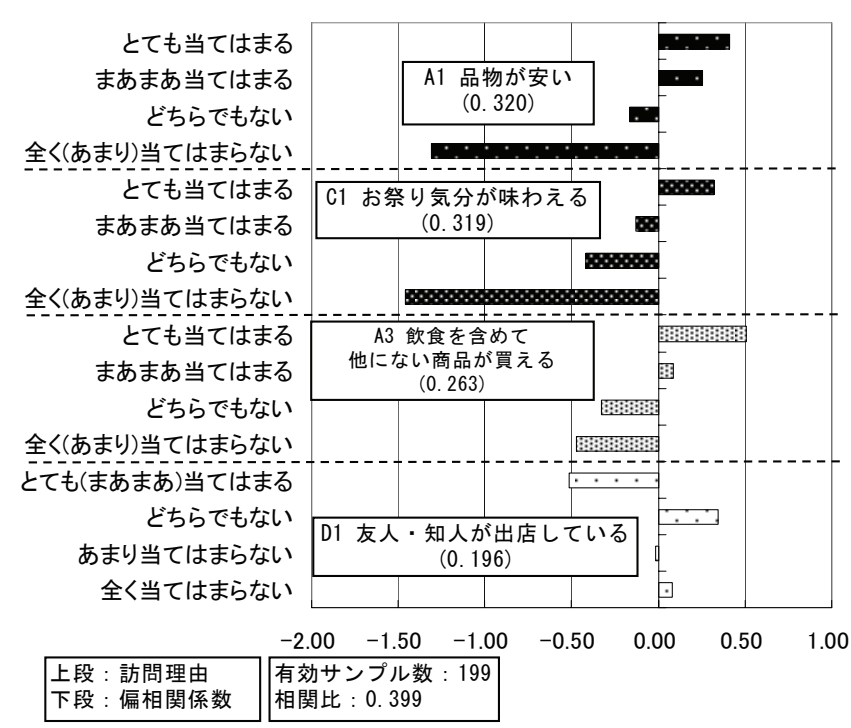

図-8 グループ来訪者における総合満足度要因分析 (数量化 II 類モデル : 偏相関係数の高い順に 4 つを掲載)

また，図-9,10にはそれぞれ一見傾向が実際と逆と思 い込まれている変数が含まれている事は興味深い. 具体 的には，まず単独来訪者において「品物が安い」が負の 影響を示している点である，図-7を見る限り，単独来訪 者は日常的買い物が主目的であり，朝市全体を見て值段 が安いということは総合的満足にプラスに影響している と考えられる. しかし, 自分がリピート来訪して品物を 購入する際には，むしろ值段に関わらず，地産池消の商 品として価值があるかどうかにこだわっているというこ とが類推される．また，グループ来訪者では広域的な観 光地である「美観地区またはチボリ公園と組合わせて楽 しめる」が負の影響を示している，これは，観光目的で たまたま美観地区やチボリ公園を訪れた遠方からの観光 客が，通りすがりに今回初めて朝市に立ち寄った（リピ 一ト客はいない）ということを示している. すなわち, グループ来訪者のリピーターはいわゆる美観地区などに 来る観光客とは異なることが明らかになった．大規模観 光施設と非定常型マーケットをセットにしてグループ来 訪をリピート化しようという試みに対し，一種の警告が 発せられたともいえよう。

\section{（3）モデル分析が示す事柄}

なお，この他にも「滞在時間」及び「支出額（一人当 たりおよび，グループ当たり）」にどのような意識が密 接に関連しているかについて，同様のモデル分析を行っ た. そこで得られた最も特徵的な結果は「グループ来訪 者の中で朝市の非日常性をより強く意識している者は, 滞在時間が長くなり, かつ支出額も多くなる」というこ とであった．また，この傾向は単独来訪者のそれと比較 して顕著なものであった。 


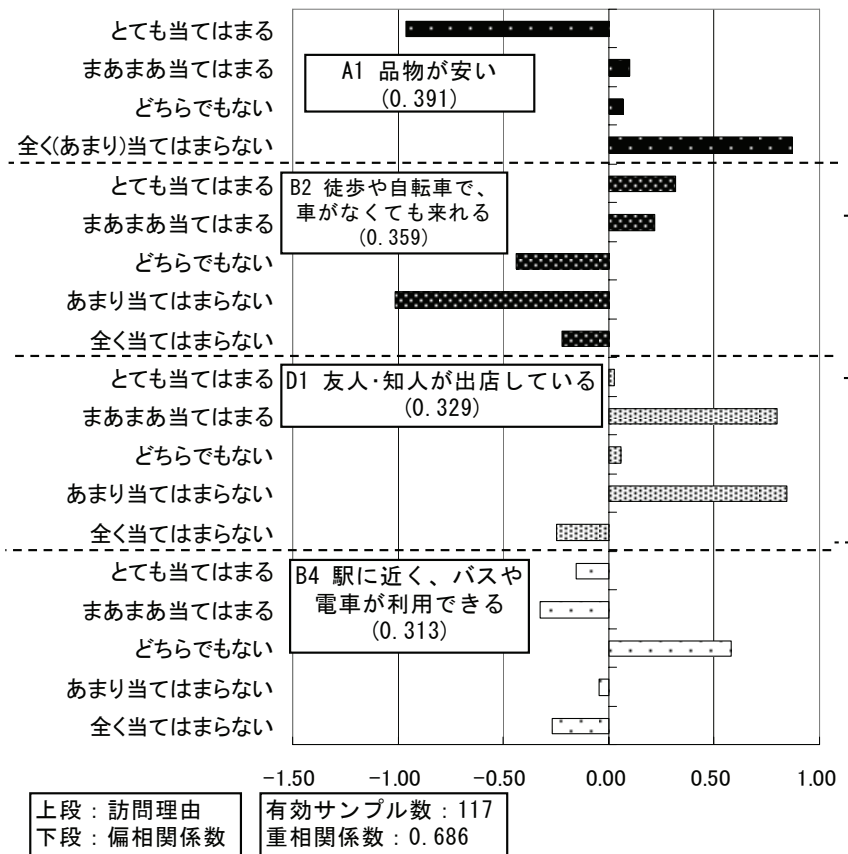

図-9 単独来訪者における訪問回数要因分析

(数量化 I類モデル : 偏相関係数の高い順に4つを掲載)

以上の分析を総合化すると，グループ来訪者は朝市を 単なる買い物の場ではなく，非日常的な身近なレジャー であると捉える傾向にあり，その傾向が強い者ほど総合 満足度は高く, リピート性，にぎわい，経済面でも都市 再生に資する可能性が高いことが示された．また，それ 之同時に，評価や行動における微妙な心理（知り合いが 出店することは来訪者の満足度向上につながらない，単 独来訪者は品物の安さを理由にリピートしているのでは ない、リピーターはいわゆる美観地区に来るような観光 客とは異なる．等）も明らかにすることができた。

\section{6. 自動車利用による環境負荷に着目した考察}

以上の分析より，グループ来訪者にとって朝市は買い 物行動というより, むしろ身近なレジャーとしての位置 づけに意味があることが定量的に示された，一方，いわ ゆる従来型の一般的な観光・レジャーはグループ来訪が 基本となっている．本章ではグループ行動の比重が高い といえる観光・レジャ一活動において, 交通環境負荷と いう観点から朝市などの都心再生型レジャースポットの 意義を簡単なデータから考える，なお，観光・レジャー 行動に着目した交通環境負荷に関する精度の高い研究は, 分析に適切なデータが存在しないこともあり, 先に述べ たような森地らの研究4)があるものの，まだ十分には取 り組まれていない，本論文では，ごく粗い検討法ではあ るが，後述する各交通手段別の二酸化炭素排出原単位 ${ }^{11)}$ を参考に, 交通手段として自家用車の選択割合が高く,

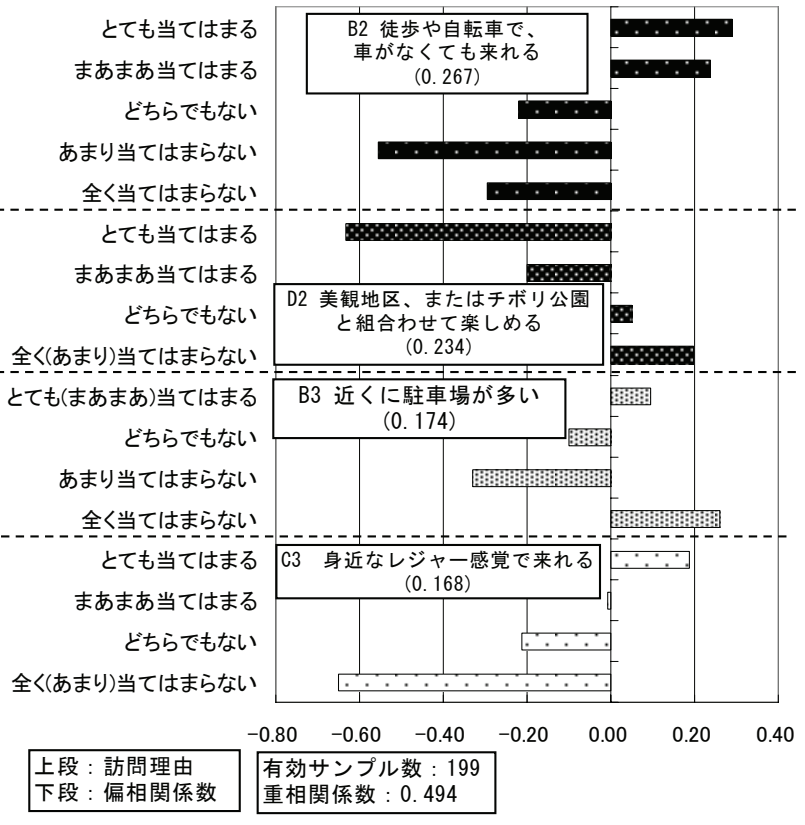

図-10 グループ来訪者における訪問回数要因分析

(数量化 I 類モデル : 偏相関係数の高い順に4つを掲載)

かつその移動距離が長い場合に環境負荷が高いと簡便に 解釈して考察を行うこととする. ミクロなレベルでの渋 滞影響などは考慮しないこととする.

\section{（1）朝市来訪者の自家用車利用距離}

第 4 章の図-2より，グループ来訪者の方が単独来訪者 よりも自家用車選択の割合が高いことが明らかになった。 この理由として, 両者の居住地分布が異なる（具体的に はグループ来訪者の方がより遠方よりやってくる）こと が原因である可能性が考えられる。このことを確認する ため, 図-11,12を作成した. この結果，以下のようなこ とが明らかとなった。

1) 図-11より，グループ来訪者も単独来訪者も「距離」 に関していえば，その居住分布（シェア）に大きな差 は存在しない. $1 \mathrm{~km}$ 以内などの徒歩圈について, 単独 来訪者のシェアが相対的にやや高くなる程度である.

2) 図-12より，利用交通手段ごとに検討を行うと，自家 用車利用者ではむしろグループ来訪者の方が朝市に近 い所に住んでいる。また，その自動車利用距離は約 12kmである.

3)これら図-11，12から，グループ来訪者の方が，自家 用車選択率が高くなることの理由を見つけることはで きない.むしろ，それがグループ行動であるというこ と自体が，自家用車の選択率を高くしている本当の理 由であると考えられる.

（2）一般的なレジャー・観光行動との比較

以上のように，朝市への自家用車によるグループ来訪 
者の居住地と朝市の間の直線距離の平均值は約 $12 \mathrm{~km}$ であ り，府県間を移動するような，いわゆる一般的なレジャ 一・観光行動の自動車移動距離と比較して，格段にその 距離は短いことが類推できる.

以下では，環境負荷を考える際のもう一つの要素であ る自家用車分担率について，岡山県内居住者のレジャー 行動 ${ }^{12)}$ (着地は未特定) や，岡山県の主要観光地を目的

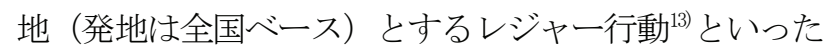
比較が可能なデータをマイニングすることにより，朝市 における自家用車分担率の特徵を明らかにする。（なお， このうち前者は「映画, 音楽会, その他のレジャー（以 下，レジャー行動）」を目的としたトリップ (有効サン プル数 : 2,636））である. 図-13にこれらの結果を示す. この図から，朝市グループ来訪者の自家用車分担率が 約 5 割であるのに対して, 岡山県居住者のレジャー行動 の自家用車分担率は約8割，県主要観光地へのレジャー 行動のそれは約5割〜約9割と高い. また，徒歩や二輪の 分担率は, 朝市が圧倒的に高いことが読み取れる.さら に，県主要観光地へのレジャー行動においては，自家用 車に次いで観光バスの分担率が高い傾向にある.

表-4の二酸化炭素排出原単位を参考にすることで, 来
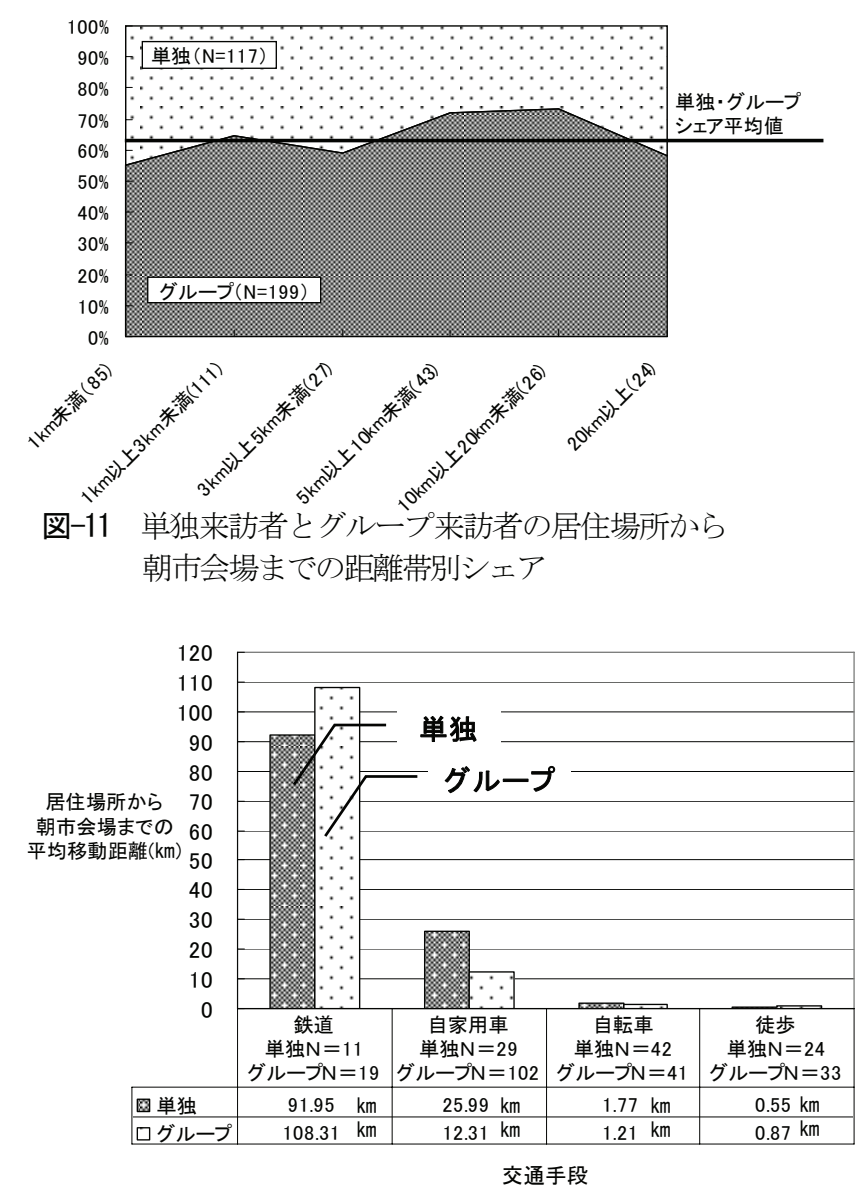

図-12 単独来訪者とグループ来訪者の交通手段別の居住 場所から朝市会場までの距離
訪者による環境負荷の面から考察すると, 岡山県内居住 者のレジャー行動や県主要観光地へのレジャー行動は, 朝市へのグループ来訪と比較して自動車利用に依存した 環境負荷の高い行動であることが容易に読み取れる。な お，ここで用いた二酸化炭素排出原単位は，自家用車等 の平均乗車人数を基に算出されていると考えられる. H11年の道路交通センサスの結果 ${ }^{14)}$ では，自家用車（乗 用車）の平均乗車人数は 1.33 人であるのに対して，朝市 のそれは2.41人（グループベース）であった. また，こ れら比較は，グループ行動を伴い，かつ観光やレジャー という同じ目的を有する行動間の環境負荷の比較検討を 行っており, 朝市が, 一般的なレジャー・観光行動と比 較して，同等，もしくはそれ以上の満足度を与えるかど うかについては考慮されていない. これらの点に解釈上 の注意が必要である.

以上のようなごく粗い，しかし今までになされていな かった基本的な比較検討から，グループ来訪行動に対し， 朝市のような都心再生型スポットは交通環境負荷が相対 的に低いことが明らかになった．複数の観光地を観光バ スや自家用車などで効率よく周る一般的な主要観光地一 のレジャー行動に対し, 徒歩などでゆったり目的地を巡 るスローツーリズムが提唱されている ${ }^{15)}$.このような朝 市などは，以上の結果からそのコンテンツとして重要な 地位を占めることが期待される.

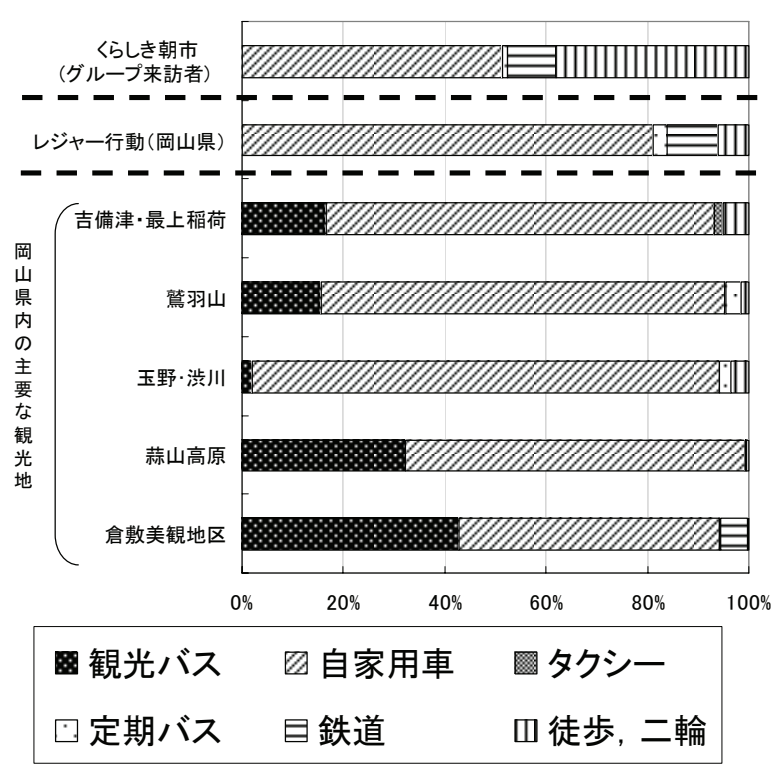

図-13 くらしき朝市と岡山県内の主要レジャー・観光 地の交通手段分担率

表-4 交通手段別の二酸化炭素排出原単位

\begin{tabular}{|l|c|c|c|c|c|}
\hline 利用交通機関洼) & 観光バス & 自家用車 & タクシー & 定期バス & 鉄道 \\
\hline \hline $\mathrm{CO}_{2}$ 排出原単位 $(\mathrm{g}-\mathrm{c} / \mathrm{Am})$ & 8 & 45 & 45 & 19 & 5 \\
\hline
\end{tabular}

注) 文献 ${ }^{11}$ の交通機関分類との対応は次のとおり：貸切バス（観 光バス）, 自家用乗用車（自家用車，タクシー），乗合バス (定期バス) 


\section{7. おわりに}

本報告では，朝市来訪者のグループ行動に着目して， 行動特性やその諸要因, そして環境影響の検討を行った。 分析の対象とすることができたのは，多岐に渡るグルー プ行動特性のごく一面でしかないが，本分析だけからで も以下の事柄が明らかになった。

1)グループ来訪者は, 単独来訪者と比較して, 自家用車 選択率が高く，その傾向は家族グループで更に顕著に なる．また，リピーターの割合も少ない，さらに滞在 時間が長いにも関わらず，一人当たり支出金額が低い，

2) 単独来訪者は朝市を日常的な買い物の代替的な役割と して捉えている. その一方，グループ来訪者は朝市を 非日常的な身近なレジャーと捉えており，その傾向が 強い来訪者ほど, 総合満足度が高く, リピート性, に ぎわい，経済面で都市再生に資する可能性がある.

3) モデル分析の結果から，グループ来訪者のリピーター は，いわゆる一般観光地である美観地区に来るような 観光客とは性格が異なることが明らかとなった。

4) 岡山県内居住者による一般的なレジャ一行動や, 岡山 県の主要観光地を目的地とするレジャ一行動と比較し, 朝市へのグループ来訪者の交通環境負荷は低く抑えら れている. 都心再生型の非定常型マーケットの導入を, 交通環境戦略の一環として取り上げることの意義が示 されたといえる.

また，今後の課題として，次の3点があげられる.

1) 本研究では全部で4つの行動特性に対して数量化モデ ルの構築を行ったが，そのいずれについてもグループ 来訪者モデルの相関比は単独来訪者のそれよりも低か った. これはグループ構成の中身が多様であるにも関 わらず，サンプル数の関係上それらをまとめてモデル 化したことに原因があると考えられる．すなわち，モ デル分析においてはグループ特性の細分化が可能なよ うに，今後さらにサンプルを確保する必要がある。

2) グループ来訪者のリピーターは，美観地区に来るよう な観光客とは同一ではないことが示された。朝市を通 じた都心再生において, 既に存在する観光施設と, こ のような非定常型マーケットによる都心再生の連携の ためには，別途の仕掛けが求められる.

3)また，本報告で定量的に明らかにされたような，レジ ヤー・観光の要素を併せもつ朝市が，一般的なレジャ 一・観光地の代替的な目的地となり得るのか, 環境面 だけではなく, その検討も求められる.
謝辞 : データ作成に際し, 難波龍也氏 (前岡山大学大学 院生), 横山大輔氏 (岡山大学大学院)のご協力をいただ いた。 また，本調査の実現においては，倉敷市建設局市 街地開発課, NP0法人まちづくり推進機構岡山, 及びく らしき朝市実行委員会のご厚意をいただいた．記して謝 意を申し上げる.

\section{参考文献}

1）たとえば，上田孝行，森杉壽芳：家族行動としての交通 行動, 土木計画学研究・講演集, No.18(1), p.444, 1995.

2) 張峻屹, 藤原章正, 杉恵頼寧, 山田敏久: 世帯内相互作 用の異質性を考慮した時間配分モデルの高齢者交通政策 分析一の適用可能性, 土木学会論文集, No.786/IV-67, pp.53-65, 2005.

3）たとえば，西井和夫，佐々木邦明，金賢，品川円宏，山 根広嗣: 観光客情報利用と周遊パターン・滞在時間特性 との関連分析, 土木計画学研究・論文集, Vol.22, No.3, pp.487-494, 2005.

4) 森地茂, 屋井鉄雄, 岡本直久 : 観光地域における交通行 動と環境影響の関連について, 土木学会第 48 回年次学術 講演会, p..518-519, 1993.

5）武藤雅威, 内山久雄 : 休日の旅客動向に基づく幹線鉄道 のサービス方策に関する研究, 土木計画学研究·論文集,

No.17, pp.745-750, 2000.

6) 土木学会土木計画学研究委員会 : http://www.jsce.or.jp/ committee/ip/index.htm，2006.11閲覽.

7) 日暮晃一, 安村碩之: 消費者行動からみた「朝市」にお ける農産物市場のセグメンテーションー神奈川県伊勢原 農業改良普及所管内にある朝市の事例分析一, 第 37 巻第 3 号, pp.21-27, 1993.

8）湯沢昭，星啓：「定期市」の特性に着目した地域型商業 施設のあり方に関する一考察, 土木計画学研究・講演集, Vol.242, pp.401-404, 2001.

9) 古屋秀樹, 西井和夫, 大山勲 : 地方都市における平休日 別購買行動の実態分析, 土木学会第 52 回年次学術講演会, pp146-147, 1997.

10) 古市英士, 松井寛, 藤田素弘 : レジャ一施設における個 人行動の分析とそのモデル化に関する研究, 土木学会第 48 回年次学術講演会, pp.520-521, 1993.

11) 日本財団図書館(電子図書館) 交通部門環境年次報告書: http:/nippon.zaidan.info/seikabutsu/2000/00486/,2005.12閲覧.

12) (財) 岡山経済研究所 : 第 9 回岡山県民の生活行動圈調查, 2001.

13）岡山県産業労働部観光物産課 : 観光客・その流れ之傾向 一岡山県観光客動態調查報告書一, 2004.

14）道路交通センサス 平成 11 年度調查結果 : http:/ /www.mlit. go.jp/road/census/, 2005..9閲覧.

15）たとえば，環境負荷に考慮した瀬戸内海スローツーリズ ム創出調查 : http://www.mlit.go.jp/kishakisha05/02/020815/03.pdf, 2005.12閲覧.

(2006.130受付) 


\section{STUDY ON GROUP BEHAVIOR IN THE CASE OF MORNING FAIR}

\section{Takehito UJIHARA, Mamoru TANIGUCHI and Ryoji MATSUNAKA}

This study aims to clarify group behavior in the case of morning fair that is held for urban renewal. The questionnaire was executed for 318 visitors (3.6\% extraction) in Kurashiki morning fair. Six indexes are examined, such as mode choice, satisfaction, visiting frequency, duration, expenditure and environment $\left(\mathrm{CO}_{2}\right)$. The result is that group visitors tend to regard that the morning fair as a leisure activity. However, visiting frequency and expenditure of group visitors were lower than those of single visitors. From environmental point of view, it is also clarified that the trip to the morning fair in city center could reduce $\mathrm{CO}_{2}$ emission compared to conventional sightseeing trip. 